\title{
EM TORNO DA PALAVRA MATRIMÔNIO
}

Bruno Bimbi (32) é argentino, jornalista, professor de português e mestrando em Letras na área de Estudos da Linguagem na Pontifícia Universidade Católica do Rio de Janeiro (PUC-RIO). Email: bbimbi@gmail.com

\section{RESUMO}

O artigo analisa as controvérsias "linguísticas" surgidas na Espanha durante o debate da lei de matrimônio homossexual, nas quais a disputa acerca da palavra matrimônio acabou sendo um dos eixos centrais da discussão sobre a lei. A nossa análise procura estabelecer certos paralelos entre alguns discursos a favor e contra o matrimônio homossexual, registrados nas atas do congresso, e as concepções sobre a linguagem presentes nas falas de Sócrates, Hermógenes e Crátilo sobre a "justeza dos nomes", recriadas no famoso diálogo de Platão no século IV a.C.

\section{RESUMEN}

El artículo analiza las controversias "lingüísticas" surgidas en España durante el debate de la ley de matrimonio homosexual, en las cuales la disputa por la palabra matrimonio acabó siendo uno de los ejes centrales de la discusión sobre la ley. Nuestro análisis busca establecer ciertos paralelos entre algunos discursos a favor y contra el matrimonio homosexual, registrados en las actas del congreso, y las concepciones sobre el lenguaje presentes en las palabras de Sócrates, Hermógenes y Crátilo sobre la "justeza de los nombres", recreadas en el famoso diálogo de Platón, del s. IV a.C.

\section{Introdução}

"Que há num simples nome? O que chamamos rosa, sob uma outra designação, teria igual perfume”, diz a Julieta de Shakespeare. Mais recentemente, uma música do cantor espanhol Joaquín Sabina propõe "recuperar de nuevo los nombres de las cosas. Llamarle pan al pan, vino llamarle al vino". Ambos os versos parecem dizer obviedades sobre aquilo a que nos referimos como "nomes" das "coisas" e expressam concepções sobre a linguagem que, embora contraditórias, fazem parte do nosso "senso comum". Enquanto a academia, nos estudos contemporâneos sobre a linguagem, vem com apreciável frequência se afastando do caminho representacionista e universalista, privilegiando uma concepção da linguagem como práxis e fazendo uma análise política, sociológica ou psicanalítica dos discursos, fora do âmbito acadêmico, o ideário da tradição platônico-aristotélica ainda parece predominar.

O objetivo deste artigo não é analisar essas perspectivas teóricas em abstrato nem analisar o porquê do predomínio da concepção representacionista no imaginário social sobre a linguagem, mas procurar compreender uma de suas conseqüências em debates sociais e políticos contemporâneos nos quais ela está presente como pano de fundo. A discussão metalinguística sobre a relação entre o sentido e a letra ultrapassa os limites da linguística, e mesmo da filosofia, e está presente em outras polêmicas — não- 
acadêmicas — que se produzem na sociedade. Analisaremos aqui em particular alguns discursos de oposição ao matrimônio entre pessoas do mesmo sexo, nos quais a luta pela "propriedade" excludente de uma palavra, "matrimônio", que é uma luta social e política, vem sendo encarada por setores conservadores da sociedade sob o disfarce de uma pretendida "objetividade científica", como se fosse uma mera discussão sobre obviedades da língua. Na nossa análise desse debate, mostraremos certos paralelos surpreendentes entre os discursos contemporâneos de oposição ao matrimônio homossexual e as concepções sobre a linguagem presentes no Crátilo de Platão.

\section{Significado e verdade no Crátilo}

No seu Crátilo, Platão apresenta um diálogo entre Hermógenes, Sócrates e Crátilo, cuja cena inicial pode causar perplexidade. Logo no início, Hermógenes relata a Sócrates que, segundo Crátilo, o nome que ele sempre usou como próprio não é correto. Que ele não se chama Hermógenes, dissera-lhe o outro, "ainda que todo o mundo te chame desse modo". A provocação de Crátilo inicia um extenso diálogo "sobre a justeza dos nomes" que oscila entre dois extremos antagônicos - convencionalista e naturalista - que podemos identificar, por exemplo, nas passagens seguintes, retiradas das primeiras páginas do texto:

HERMÓGENES - (...) Para mim, seja qual for o nome que se dê a uma determinada coisa, esse é seu nome certo; e mais: se substituirmos esse nome por outro, vindo a cair em desuso o primitivo, o novo nome não é menos certo do que o primeiro. (...) Nenhum nome é dado por natureza a qualquer coisa, mas pela lei e o costume dos que se habituaram a chamá-lo dessa maneira (384-d).

SÓCRATES - (...) o nosso legislador deverá saber formar com os sons e as sílabas $\mathbf{0}$ nome por natureza apropriado para cada objeto, compondo todos os nomes e aplicando-os com os olhos sempre fixos no que é o nome em si, caso queira ser tido na conta de verdadeiro criador de nomes $(389-a)^{1}$.

Mais adiante, Sócrates provoca Hermógenes quanto à possibilidade de ser justa a afirmação de Crátilo que tinha dado início à discussão: o nome Hermógenes, que significa "filho de Hermes", não poderia ser jamais o nome dele: "De todo jeito, quer parecer-me que o nome Hermes se relaciona com discurso: é intérprete, ou mensageiro e também trapaceiro, fértil em discursos e comerciante labioso, qualidades essas que assentam exclusivamente no poder da palavra" (408-a). Hermógenes, logo, admite: 
"Então, parece que Crátilo tem mesmo razão de dizer que não me chamo Hermógenes, pois sou jejuno em matéria de discursos" (408-a).

Ao longo do diálogo, frequentemente considerado aporético, vemos que Platão, pela voz de Sócrates, reconhece que uma mesma coisa pode receber diferentes nomes, mas haveria um "nome em si" para cada parcela do real que os nomes particulares de cada língua ou de cada época, feitos com ferro diferente, mas com a mesma forma, refletiriam. Ele recorre à figura do legislador, que seria o encarregado de fazer os nomes, da mesma maneira que o ferreiro faz instrumentos de ferro. É que os nomes devem ser feitos da maneira essencialmente adequada e pela pessoa adequada, da mesma maneira que acontece com os outros fazeres do mundo (387-a - 390-e).

A filosofia da linguagem presente em Platão não pode se dissociar da sua ontologia ou compreensão da natureza do real, que distingue as coisas assim como as percebemos, por um lado, e a sua natureza essencial, por outro. No célebre Mito da caverna (que, lembremos, conta a história de um homem preso em uma caverna que só conhece o mundo através de sombras e, um dia, é libertado e consegue sair e ver o mundo tal como ele é), Platão ilustra essa oposição entre o mundo que os sentidos nos permitem ver e a essência das coisas tal como realmente são. Essa essência, no entanto, não é uma ideia na nossa mente, mas tem uma existência real e autônoma.

Se essa é a maneira de ver "a realidade das coisas", a linguagem nada mais é do que um instrumento para falar a respeito delas e para separá-las, tal como a lançadeira separa os fios da tela (389-a - 390b). A figura do legislador, presente em um dos trechos citados do Crátilo, representa o "fazedor de nomes" que Platão compara ao carpinteiro que faz o tear: assim como o carpinteiro constrói o tear com materiais diferentes, mas de acordo com uma forma ideal, o "tear em si", o legislador deve ser capaz de reproduzir "a idéia do nome, a propriedade para cada coisa, pouco importando as sílabas de que se valha" (390-b). Por isso, "os nomes das coisas derivam de sua natureza" e "nem todo homem é formador de nomes, mas apenas o que, olhando para o nome que cada coisa tem por natureza, sabe como exprimir com letras e sílabas sua idéia fundamental" (390-e).

Se no Crátilo opõem-se e alternam-se argumentos contrários e favoráveis às posições convencionalista e naturalista, parece claro que, qualquer que seja a posição que se tome, sublinha-se ali a tese de que "a linguagem deve transcender as nossas 
opiniões, respondendo (...) não à comunidade, mas à realidade"; as palavras "não teriam por vocação representar as coisas aparentes, variáveis e múltiplas por definição, mas antes as suas essências (...), não a realidade fenomênica, mas a realidade essencial" (Martins, 2009, p. 461).

O ponto de vista realista e essencialista de Platão, segundo o qual a linguagem é por vocação um sistema de representação, vai se opor fortemente ao olhar pragmático ou relativista, associável ao pensamento dos sofistas, seus grandes rivais. Para eles, lembremos, as coisas não têm medida ou essência própria; são aquilo que nos parecem ser, variando de acordo com as circunstâncias. Nas famosas palavras de Protágoras, "o homem é a medida de todas as coisas". Sob esse ângulo, a linguagem não pode representar a realidade: é, antes, "um grande soberano, que com o mais diminuto e inaparente corpo as mais divinas obras executa" (Górgias, Elogio de Helena, $\mathrm{n}^{\circ}$ 8).

Esse investimento contra os sofistas e sua insinuação da potência demiúrgica da linguagem fica patente em muitas passagens do Crátilo, uma das quais citamos agora pela sua relevância para este trabalho. Hermógenes parece a princípio aderir ao convencionalismo, mas sua tese logo se revela extremadamente ingênua, já que reconhece a faculdade individual de cada falante para atribuir nomes em cada ato de fala, tornando impossível a própria idéia de convenção (385-a). Seguidamente, Sócrates parece convencê-lo da incorreção desse argumento, valendo-se do seguinte raciocínio: se uma pessoa pudesse chamar uma coisa de cavalo e outra pessoa pudesse chamar a mesma coisa de homem, e ambos os nomes fossem corretos, não haveria maneira de distinguir uma proposição falsa de uma verdadeira: uma mesma proposição declarativa como "um cavalo tem quatro patas" poderia ser ora falsa e ora verdadeira, a depender do significado atribuído aos nomes em jogo. Em espírito semelhante, Aristóteles mais tarde garante a estabilidade do sentido afirmando que as coisas e as "afecções da alma" (suas representações internas) "são as mesmas para todos" (De Interpretatione, 16a3), o que permitiria, desde que se fale a mesma língua, julgar o valor de verdade das proposições declarativas. Assim, o clássico silogismo

Todos os homens são mortais.

Sócrates é homem.

Logo, Sócrates é mortal. 
só pode funcionar se tivermos a garantia de que quando falamos "homem", "mortal" ou "Sócrates" esteja bem claro do que estamos falando; o significado das palavras não pode deslizar entre uma linha e outra do silogismo.

Em resumo, a Platão e Aristóteles, dois pensadores que inauguram uma filosofia cujo legado se estende até os nossos dias, podemos atribuir a gestação do embrião de uma maneira representacionista de entender a linguagem, preocupada com a estabilidade do sentido e com o valor de verdade das proposições declarativas. Esses pressupostos ainda estão embutidos no nosso imaginário e, como veremos ao longo deste trabalho, evidenciam-se cada vez que manifestamos o que pensamos a respeito da linguagem e da verdade das coisas. Mesmo que não tenhamos lido o Crátilo nem De Interpretatione ou que não tenhamos nunca ouvido falar em Platão ou Aristóteles.

\section{O debate sobre o matrimônio entre pessoas do mesmo sexo na Espanha}

Em 21 de janeiro de 2005, o Congresso dos Deputados da Espanha iniciou formalmente o tratamento do projeto de lei de reforma ao Código Civil que legalizaria o matrimônio entre pessoas do mesmo sexo. O projeto tinha sido apresentado às câmaras pelo presidente do governo espanhol, José Luis Rodríguez Zapatero - que tinha assumido, durante a campanha eleitoral que o levou à presidência, o compromisso de promover essa reforma - , e provocou um intenso debate no Congresso, na imprensa, nas ruas e na sociedade espanhola como um todo. $\mathrm{O}$ projeto foi discutido pelos deputados nos dias 17 de março e 21 de abril. No primeiro debate, foram rejeitadas as emendas propostas pelos partidos oposicionistas e no segundo debate, a câmara deu meia sanção ao projeto. Depois, em 22 de junho, ele foi vetado pelo Senado, mas, no dia 30 daquele mês, voltou ao Congresso dos Deputados e foi sancionado em forma definitiva. No dia seguinte, a lei foi promulgada pelo Rei Juan Carlos I.

Durante o debate, dois foram os assuntos que geraram mais controvérsia: a adoção de crianças e o uso da palavra "matrimônio". Embora vários projetos de lei de "união civil" tivessem sido debatidos nos anos anteriores, sempre rejeitados pelas bancadas de direita, agora os deputados dessas facções propunham aprovar "por unanimidade" uma lei de "união civil" como alternativa ao matrimônio, exclusiva para casais 
homossexuais. Eles afirmavam que eram contrários apenas à possibilidade de que as uniões de gays e lésbicas recebessem a denominação de "matrimônio", mas que votariam a favor de uma lei que lhes garantisse os mesmos direitos dados aos casais heterossexuais, excluindo somente a adoção de crianças. A maioria das intervenções dos congressistas no debate, tanto no Senado quanto no Congresso dos Deputados, esteve centrada, portanto, nesses dois assuntos.

O que nos interessa, no presente trabalho, é o debate sobre o nome: durante alguns meses, a semântica, a etimologia e a filosofia da linguagem dominaram a discussão política e social no parlamento, na imprensa e na sociedade espanholas, e gostaríamos de entender por quê.

No editorial do site da Cope, uma emissora de rádio vinculada à igreja católica espanhola, Cristina López Shlichting escreveu:

Estes que agora nos governam - os que os sustêm - não sabem o que fazem nem o que dizem. "Matrimônio" é uma palavra que vem de "mater", mãe, que implica maternidade e filiação biológica. 'Matrimônio homossexual' é uma expressão que distorce gratuita e gravemente a linguagem ao serviço de uma ideologia minoritária, contrária ao serviço comum, ao sentir da maioria ${ }^{2}$ dos cidadãos. Também a Real Academia ${ }^{3}$ deveria fazer ouvir a sua voz $^{4}$ (Shlichting, "Distorsión del lenguaje").

Pré-anunciava assim os argumentos que seriam repetidos durante meses. No jornal El Mundo, em 20 de janeiro, José Antonio Marina assinou uma coluna que afirmava:

As fontes lexicais e legais que consultei dizem que em $1978^{5}$ a palavra "matrimônio" significava "união de um homem e uma mulher". A nova lei pode dar à palavra um outro significado, mas essa mudança pode ser retroativa? Pode significar no texto constitucional o mesmo que vai significar depois da aprovação da lei? Não, porque a segurança jurídica implica estabilidade semântica. Eu já disse que ia comentar um tema linguístico (Diario El Mundo, 2005a).

Em 5 de fevereiro, a Real Academia informou à imprensa que

se o projeto de lei sobre matrimônio entre pessoas do mesmo sexo for aprovado, levará consigo, além de efeitos jurídicos, "uma generalização do emprego da palavra 
matrimônio e as restantes de sua mesma família semântica para fazer referência também a essa nova realidade social da união de pessoas do mesmo sexo reconhecida legalmente". Caso tal ampliação de significado se consolidasse no uso geral dos hispano-falantes, a Academia Espanhola assegura que o verbete do dicionário correspondente a 'matrimônio' deveria incluir também essa acepção, como alguns dicionários de outras línguas têm feito (Diario Clarín, 2005).

Do lado dos defensores da proposta do governo, Manuel Hidalgo escreveu, em 17 de junho, no jornal El Mundo:

Há quem argumente contra o matrimônio homossexual com a definição que o dicionário dá a "matrimônio". O dicionário sempre vai por trás da vida e suas definições nem sempre se atêm a versátil realidade das coisas que são. Há coisas que existem e ainda não estão no dicionário. Já vão estar (Diario El Mundo, 2005b).

Por sua vez, Juan Manuel de Prada se referiu numa coluna do jornal $A B C$, em 30 de abril, ao fato de o debate estar centrado no aspecto lingüístico. Para ele, as pessoas que se opunham ao matrimônio, temerosas de serem chamadas de homofóbicas, estavam desviando a discussão:

Esforçam-se por desviar o debate até um terreno puramente nominalista, aceitando que tais uniões sejam celebradas, mas sob nomes diversos que deixem a salvo a designação de "matrimônio" referida exclusivamente à união entre um homem e uma mulher, reduzindo assim a discussão à uma busca um tanto bizantina de sinônimos ou alternativas semânticas (Diario $A B C, 2005)$.

Durante o primeiro debate no Congresso dos Deputados, vários legisladores se referiram à discussão linguística sobre o matrimônio homossexual. "Qual é a questão de fundo que hoje debatemos aqui?", perguntou-se a deputada Ana Torme Pardo ${ }^{6}$, do Partido Popular (partido que se opôs à lei), e respondeu a si mesma:

Não deveria ser outra que a de abordar o convívio em casal de pessoas do mesmo sexo mediante um estatuto jurídico que atribuísse direitos e obrigações, se quiser, análogos aos que derivam do matrimônio, mas sem que essa regulação supusesse uma quebra, uma alteração substancial da instituição matrimonial.

Logo depois, o deputado Luis Mardones Sevilla, da Coalición Canaria (a favor), reconheceu que "o tema é polêmico do ponto de vista ideológico, jurídico e inclusive etimológico e semântico, pela palavra matrimônio". Usando da ironia, a deputada María Carmen García Suárez, da bancada da Izquierda Unida - Izquierda Verde - 
Iniciativa per Catalunya Verds (a favor), perguntou: "querem tratar de maneira diversa, dizem, aquilo que é diferente (...) diferente de quem? Do senhor? De mim? De quem? Estão dispostos a conceder todos os reconhecimentos legais e jurídicos (...), todos menos o sagrado matrimônio". A deputada do Grupo Parlamentario Vasco (a favor), Margarita Uría Etxebarría, expressou que não acreditava na sinceridade do argumento linguístico dos oposicionistas, já que eles propunham aprovar uma lei de "união civil" análoga ao matrimônio, mas com outro nome, depois de ter rejeitado essa possibilidade durante os oito anos em que governaram o país. Ela disse que, por causa disso, achava essa proposta "cínica". Julio Villarrubia Mediavilla, deputado do governista PSOE (Partido Socialista Obrero Español), completou a acusação de Uría Etxebarría, lembrando que os legisladores do Partido Popular tinham votado contra a "união civil" 31 vezes.

Foi, no entanto, o ministro da Justiça, Juan Fernando López Aguilar, quem se referiu de maneira mais direta à discussão linguística no primeiro debate dos deputados. No seu discurso, que inaugurou a sessão, ele disse:

Nós ouvimos argumentações de caráter naturalista em duas versões, ao menos: uma de ordem etimológica e uma segunda de ordem finalista. A etimológica é a que pretende que as instituições jurídicas sejam escravas das palavras que as definem e que traçando a genealogia de uma palavra ou sua etimologia podemos encerrar um conceito até o ponto de fazê-lo completamente inválido para a sua modificação pelo legislador. Não concordamos com isso. (...) Se assim fosse, o "salário" teria de continuar sendo uma retribuição em espécie, em sal, e se assim fosse, a "pátria potestade" não seria acessível às mulheres, porque a etimologia é a que assinala a filiação com o pai, não com a mãe. A "pátria potestade" é hoje perfeitamente predicável das mulheres porque não fez falta mudar a etimologia da palavra para introduzir no léxico a "mátria potestade".

No segundo debate, a deputada Uría Etxebarría reconheceu que, dentro da sua bancada, não havia uma posição comum. Ela explicou que todos os deputados e as deputadas do Grupo Parlamentario Vasco eram a favor da igualdade de direitos para os casais homossexuais - inclusive o direito à adoção de crianças —, mas alguns eram contra o uso da palavra "matrimônio" para se referir às uniões legais entre dois homens ou duas mulheres. Por essa razão, o grupo tinha decidido conceder liberdade de consciência para que cada deputado ou deputada votasse segundo as suas convicções.

Explicou Etxebarría:

Todos somos partidários de que a integralidade de direitos das pessoas homossexuais e 
heterossexuais há de ser idêntica nas relações de família. A variedade na distinção de votos, se houver, estará em que se dê, ou não, o "nomen iuris" "matrimônio" à instituição.

Também a deputada Carmen Montón Giménez, do PSOE, referiu-se à polêmica sobre o nome: “O direito de contrair matrimônio e de designá-lo 'matrimônio' é um direito de todos sem distinção".

No debate no Senado, onde a oposição de direita era maioria e conseguiu impor o veto à lei, a discussão "linguística" esteve ainda mais presente do que nos debates anteriores.

"O matrimônio, vossas senhorias, é 'a união de homem e mulher concertada mediante determinados ritos e formalidades legais", disse a senadora María Rosa Vindel López, do Partido Popular, citando de cor o verbete do dicionário ${ }^{7}$ da Real Academia. "Portanto, a heterossexualidade é um elemento constitutivo essencial do próprio conceito de matrimônio. Ele é heterossexual ou não é, porque o dado da heterossexualidade aparece com toda naturalidade como um elemento indiscutível e óbvio". Logo depois, veio a fala do senador Arcadio Díaz Tejera, do PSOE, que respondeu:

A que se deve tal batalha pela palavra? Se dizem que agora se procura - não durante os últimos oito anos, porque a linguinha tinha sido comida pelo gatinho ${ }^{8}$ durante os últimos oito anos - a equiparação em matéria de direito sucessório, de direito tributário, de seguros, (...), se dizem isso tudo, por que quando dizem "podemos equipará-los em tudo" existe esse temor ao uso da palavra? É apenas um debate nominal? É um debate em torno do "nomem”, a chamá-lo ou não matrimônio? Não entendo qual é o sentido disso.

A senadora Isabel López Aulestia, do Grupo Parlamentario Mixto, também entrou na discussão sobre o que pode e o que não pode ser chamado de "matrimônio": segundo a senadora, o matrimônio pode ser

o que os cidadãos e as cidadãs democraticamente decidirem que seja. Isso é só o que pode ser. Nós podemos decidir hoje que o matrimônio é isto e daqui a alguns anos decidir que ele é outra coisa. Recorrer a definições essencialistas é algo que está fora desta câmara, ou ao menos deveria estar fora desta câmara e da política.

No entanto, José María Mur Bernard, um senador da mesma bancada que não compartilhava da opinião dela, disse depois que "aspectos como o "nomen iuris" ou a denominação da união conjugal homossexual poderiam ter sido modificados sem 
nenhum prejuízo para os direitos cíveis dos homossexuais, respeitando, isso sim, outras sensibilidades".

Mais dois senadores opinaram sobre o debate lingüístico. O senador Félix Ayala Fonte, da Coalición Canaria, além de expressar sua opinião favorável ao projeto, refletiu sobre o próprio fato de os senadores estarem discutindo sobre verbetes de dicionário:

Muitos daqueles que se opõem a esta lei o fazem, segundo dizem, pelo uso da palavra "matrimônio" para nomear esta união. É verdade que etimologicamente significa o que significa, mas se hoje, em prol do consenso, nós lhe pusermos um outro nome, o certo é que o cidadão comum continuará chamando de “matrimônio" e, afinal, dentro de poucos anos, os acadêmicos não terão outro remédio a não ser incluir essa nova acepção no dicionário.

Por sua vez, a senadora Elena Etxegoyen, do Partido Nacionalista Vasco (a favor), advertiu que esse tipo de discussão contradizia a própria função do legislador: "Não adianta invocar, como também foi feito, razões de ordem etimológica, porque nunca as instituições jurídicas podem ser escravas do termo que as define, porque a função do legislador - e em grande medida, isso é que somos — deviria inútil".

A última citação do debate parlamentar espanhol que colocaremos aqui corresponde à fala da deputada governista Carmen Montón Giménez, do PSOE, no debate final no Congresso dos Deputados, que derrubou o veto do Senado e sancionou a lei de matrimônio entre pessoas do mesmo sexo. Esta legisladora se referiu de maneira elíptica à oposição "linguística" ao projeto, usando da ironia para falar do "nome das coisas":

Chega de desculpas e de rodeios, chamemos as coisas pelo seu nome; chamemos a cada coisa pelo seu nome, não usemos eufemismos. A querer manter a discriminação por motivos de orientação sexual se chama "homofobia"; a querer dar um trato de inferioridade a alguns indivíduos ou a uma coletividade se chama "discriminação"; quando se quer que apenas um e não todos os cidadãos desfrutem de vantagens que sejam especiais ou exclusivas, como o direito ao matrimônio, este deixa de ser um direito e se chama "privilégio", e a fingir ou aparentar o que não é ou o que não se sente, a dizer uma coisa e fazer outra, se chama "hipocrisia".

Mesmo depois de sancionada a lei e da celebração dos casamentos de milhares de lésbicas e gays, o debate linguístico continuou, agora no âmbito da Real Academia e das instituições análogas das línguas catalã, valenciana, etc.

$\mathrm{Na}$ Espanha convivem várias línguas, embora o castelhano ${ }^{9}$ seja o idioma oficial do Reino, e foram os valencianos e os catalães que deram o primeiro passo nesse segundo capítulo do debate linguístico sobre o matrimônio homossexual. O Institut d'Estudis Catalans (IEC) decidiu mudar o antigo verbete de "matrimoni" no dicionário dessa língua ("união legítima entre um homem e uma mulher”) por "união legítima entre duas pessoas que se comprometem a levar uma vida em comum estabelecida mediante ritos e formalidades legais". Por sua vez, segundo um projeto de atualização 
do Diccionari Normatiu Valencià aprovado pela Acadèmia Valenciana de la Llengua, a nova definição da palavra será: "união legal de duas pessoas de sexo diferente e, em alguns países, do mesmo sexo". A FELGT ${ }^{10}$ iniciou uma campanha pública para solicitar à Real Academia Española que mudasse o verbete no dicionário oficial dessa língua, eliminando a definição exclusivamente heterossexual, que, a partir da mudança da lei que permitiu que gays e lésbicas pudessem aceder a essa instituição, contradiz as práticas linguísticas dos hispano-falantes ${ }^{11}$. Durante o debate da lei, quando o argumento do dicionário foi utilizado, a ex-presidente da FELGT, Beatriz Gimeno, disse: afinal, os dicionários terão de se adaptar à realidade, e não a realidade aos dicionários".

\section{O debate sobre o matrimônio entre pessoas do mesmo sexo na Argentina e a explicitação do confronto de argumentos linguísticos num processo judicial}

O que aconteceu com o debate na Espanha está se repetindo em outros países, cada vez que o direito ao matrimônio entre pessoas do mesmo sexo entra no debate público. Muitos setores políticos que, antigamente, eram contra qualquer tipo de reconhecimento de direitos para os casais homossexuais, têm mudado nos últimos anos seus discursos e agora, mais "politicamente corretos", falam em igualdade e nãodiscriminação. Dizem que aceitariam votar leis que reconheçam direitos iguais ${ }^{12}$, mas se opõem a que a instituição jurídica usada para o reconhecimento legal das uniões de pessoas do mesmo sexo seja chamada de "matrimônio".

$\mathrm{Na}$ Argentina, a campanha pela legalização do matrimônio entre pessoas do mesmo sexo, iniciada pela Federação Argentina de Lésbicas, Gays, Bissexuais e Transexuais, adotou o lema que já tinha sido usado pela FELGT espanhola: "Os mesmos direitos com os mesmos nomes". Um casal de lésbicas e três casais de gays abriram processos na Justiça para que a lei de matrimônio ${ }^{13}$ seja declarada inconstitucional e, nos fundamentos do texto apresentado à Justiça ${ }^{14}$, explicitaram e ordenaram os argumentos conhecidos de oposição ao uso da palavra "matrimônio" para se referir às uniões legais entre pessoas do mesmo sexo, antecipando uma resposta a cada um deles. As respostas, em muitos casos, reproduziram ou ampliaram as que já tinham se expressado na Espanha, mas a novidade foi que o próprio debate institucional se iniciasse com uma formulação organizada de argumentos e contra-argumentos, que foi possível a partir do estudo do debate espanhol.

Mostraremos agora, tendo em vista os nossos objetivos aqui anunciados, que a cada um dos argumentos de oposição ao matrimônio gay listados neste texto podemos associar as falas de Sócrates, Hermógenes e Crátilo, presentes no diálogo platônico acima descrito, com as quais, na nossa opinião, eles dialogam : 
a) Que a palavra "matrimônio" vem de "mater", que significa “mãe”, então não poderia existir entre dois homens. A exploração dialógica de Sócrates sobre a origem dos nomes ocupa várias páginas do Crátilo com uma série de análises etimológicas desse tipo. Um exemplo: “Quanto ao ar, Hermógenes, ou foi denominado aêr porque levanta (airei) da terra as coisas, ou porque se encontra sempre a puxar (aei rhei), ou porque com o seu movimento produz o vento. Os poetas dão ao vento o nome de aêtas" (Crátilo, 410-b).

b) Que o dicionário define a palavra “matrimônio" como "a união entre um homem e uma mulher” 15 . Em muitas passagens do diálogo, podemos encontrar um apelo semelhante à autoridade, a uma fonte indubitável de verdade sobre a justeza dos nomes: "Qual dos dois nomes, então, achas que Homero considerava mais certo para o menino: Astianacte ou Escamândrio?” (Crátilo, 392-b), “Ou serás da opinião que carece de fundamento o que eu disse e que me iludo quando imagino seguir no rasto da opinião de Homero acerca da justeza dos nomes?" (Crátilo, 393-b).

c) Que a palavra "matrimônio" sempre foi usada para se referir à união entre um homem e uma mulher, nunca para uniões homossexuais. Como já se disse, podemos identificar no Crátilo um apelo à necessidade de que os sentidos das palavras sejam estáveis. Embora Sócrates por vezes sugira ser talvez "a idade dos vocábulos" o que torna impossível reconhecer a relação natural entre o nome e a coisa, insiste, no entanto, na necessidade de que ela seja fixa e objetiva, ainda que convencional. Pois, "Nem seria mesmo razoável afirmar, Crátilo, a possibilidade do conhecimento, se todas as coisas se transformam e nada permanece fixo. (...) Se sempre se transformasse, nunca poderia haver conhecimento e, pela mesma razão, não haveria alguém que conhecesse, como também não poderia haver objeto de conhecimento" (Crátilo, 440-a).

d) $\mathbf{O}$ matrimônio só pode existir entre homem e mulher porque a finalidade dele, inscrita na etimologia (“mater”) é a procriação. Novamente, um paralelo pode ser aqui estabelecido com as explorações etimológicas do Crátilo. Há na origem do nome Hermógnes (filho de Hermes), como na do nome 'matrimônio', uma indicação sobre os atributos daquilo que essas palavras vêm nomear, o que fica patente na seguinte passagem, já citada: "de todo jeito, quer parecer-me que o nome Hermes se relaciona com discurso: é intérprete, ou mensageiro, e também trapaceiro, fértil em discursos e comerciante labioso, qualidades essas que assentam exclusivamente no poder da palavra" (Crátilo, 408-a).

e) Que “o matrimônio nasce da natureza”, é "naturalmente” heterossexual e isso está na sua "essência”. O essencialismo cratílico é aqui nítido. A idéia de que os nomes provêm da natureza e refletem a "essência" das coisas é recorrente no diálogo: “(...) Crátilo tem razão de dizer que os nomes das coisas derivam de sua natureza e que nem todo homem é formador de nomes, mas apenas o que, olhando para o nome que cada coisa tem por natureza, sabe como exprimir com letras e sílabas sua idéia fundamental" (Crátilo, 390-e). 
f) Etc.

Cada um dos argumentos listados foi respondido no texto da ação de amparo apresentada por Rachid e Castro, o primeiro casal de lésbicas que entrou com um processo na justiça contra a lei de matrimônio (Bimbi et alii, $2008^{16}$ ):

a) O argumento "etimológico" foi questionado a partir de exemplos como: "salário" (antigamente pago em sal, hoje em dinheiro), "patria potestade" (antigamente reservada ao pai, como sua etimologia indica), "patrimônio" (era também exclusivo do homem). Além disso, o texto da ação judicial lembra que, da mesma maneira que "mater" significa "mãe", "monı̌um" significa "gravame", o que pode ser entendido como uma descrição da "maior carga" que a mulher levava no matrimônio, segundo é afirmado em alguns tratados de direito de família. No entanto, essa idéia do matrimônio heterossexual não parece tão plausível na atualidade. Também há no texto um questionamento teórico à própria idéia de que a etimologia seja uma voz autorizada para determinar o significado de uma palavra, já que as línguas variam e mudam, e são apresentados conceitos como "deslocamento semântico", "extensão" etc.

b) $\mathrm{O}$ argumento do dicionário foi questionado com exemplos como o verbete que define "judeu" como: "indivíduo avaro, usurário"17, e outros que contêm, também, preconceitos e concepções discriminatórias. Também há um questionamento mais teórico à própria ideia de que o dicionário seja uma voz autorizada para determinar o significado de uma palavra, que estaria no uso.

c) $\mathrm{O}$ argumento do "significado histórico da palavra" foi rebatido com dados históricos sobre as mudanças que a instituição do matrimônio teve (os negros não podiam casar, os não-católicos não podiam casar, depois os negros não podiam casar com brancos, as mulheres não podiam eleger o marido, etc.) e se afirma que, até o século IV, os matrimônios entre homens (o que, naquela época, podia ser chamado de matrimônio ${ }^{18}$ ) eram legais e, de fato, existiram. Também há um questionamento mais filosófico à ideia de que uma coisa deva permanecer como sempre foi, o que impediria qualquer mudança e deteria a história (os negros sempre foram escravos até que a escravidão foi abolida, as mulheres não podiam votar até que conquistaram esse direito, etc.). Da mesma maneira, afirma-se, citando, entre outros, Saussure, como as coisas mudam, as línguas também tem de mudar.

d) O argumento que define a palavra "matrimônio" por uma suposta finalidade, como uma instituição destinada "à procriação e à preservação da espécie", o que se justificaria, novamente, pela presença de um prefixo, “mater”, que etimologicamente significa “mãe”, foi rejeitado a partir de exemplos tirados do próprio matrimônio heterossexual e da realidade de muitos casais homossexuais com filhos:

Se fosse assim, deveria ser instaurado um exame de fertilidade prévio ao matrimônio, como pré-requisito do ato. Não só isso, o matrimônio deveria ser proibido aos casais 
heterossexuais que decidissem, por vontade própria, não ter filhos, e deveriam ser anulados os matrimônios dos casais heterossexuais que não tivessem filhos depois de certo tempo. Aliás, as pessoas homossexuais não são estéreis e muitos casais de homens ou de mulheres têm filhos por diversos métodos; por exemplo, no caso dos casais de lésbicas, mediante as técnicas de fertilização assistida. O vazio legal existente priva essas crianças de direitos e as põe num plano de cidadania de segunda categoria; o mesmo que acontece com seus pais ou mães (Bimbi et alii, 2008).

e) Com relação ao argumento da natureza ${ }^{19}$, ele foi respondido pelo autor desse trabalho num artigo publicado no jornal conservador La Nación, que tinha defendido num editorial a tese de que o matrimônio provém da natureza:

Foi dito também que o matrimônio é heterossexual porque provém da natureza. Da natureza, como as plantas e os rios e as tormentas e os animais e os homens e as mulheres? Não foi o matrimônio uma invenção humana? Existe desde que o mundo é mundo ou foi criado num determinado momento da civilização? Foi sempre igual, imutável, ou sofreu grandes mudanças ao longo de sua história? Será que a fidelidade, a monogamia, o patrimônio, o sobrenome, a herança, a pátria potestade, as pensões, os planos de saúde, a nacionalidade são fatos da natureza? São construções sociais!

(...) O que provém da natureza sim é isto: sentir que a pele se eriça, que o coração bate mais forte; sentir-se irremediavelmente atraído por esse olhar, por esse corpo, por esse outro ou essa outra, enredar-se, amar-se, decidir que queremos estar juntos ou juntas, que queremos compartilhar a vida. Isso é que é natural (Bimbi, 2007).

Voltemos ao Crátilo para analisar com mais detalhe alguns desses argumentos.

O site da ACI (Agência Católica de Informações: www.aciprensa.com), em todos os textos que publica, distingue o uso da palavra 'matrimônio' para se referir à união entre um homem e uma mulher do uso da mesma palavra para se referir à união entre dois homens ou duas mulheres... Nos últimos casos, a palavra sempre é colocada entre aspas. "O matrimônio é heterossexual ou não é", disse a deputada Vindel López no Congresso dos Deputados. “"Matrimônio homossexual' é uma expressão que distorce gratuita e gravemente a linguagem”, escreveu López Shlichting no texto citado mais acima. Isso nos faz lembrar Crátilo falando a Hermógenes: esse nome que usas não é teu; tu não és Hermógenes.

-Por quê?

—Porque Hermógenes é filho de Hermes, que é mestre do discurso, e tu não és um bom orador.

-Por quê?

—Porque 'matrimônio' vem de 'mater', que significa 'mãe', e tu não podes procriar.

O uso da etimologia como fonte privilegiada que diz sobre o significado "correto" 
das palavras pode ser encontrado no próprio Crátilo, nas explicações de Sócrates sobre a origem dos nomes. E a figura do legislador, que Platão introduz nesse texto, embora não se refira, é claro, ao legislador que trabalha no Congresso dos Deputados, nos oferece uma analogia que parece perfeita: o que estava sendo discutido pelos legisladores espanhóis era a possibilidade de eles legislarem sobre um nome, no caso, "matrimônio", e como essa tarefa deveria ser feita.

Alguns legisladores afirmavam que a "essência" ou a "natureza" da palavra "matrimônio" já estava determinada, e que não correspondia a estes legisladores (sim, talvez, à figura platônica do legislador, que já teria agido) a faculdade de mudar algo que é, por si, imutável. "A heterossexualidade é um elemento constitutivo essencial do próprio conceito de matrimônio. O matrimônio ou é heterossexual ou não é". "O nosso legislador deverá saber formar com os sons e as sílabas o nome por natureza apropriado para cada objeto, compondo todos os nomes e aplicando-os com os olhos sempre fixos no que é o nome em si, caso queira ser tido na conta de verdadeiro criador de nomes". Outros respondiam: "Nós podemos decidir hoje que o matrimônio é isto e daqui a alguns anos decidir que ele é outra coisa". "O homem é a medida de todas as coisas"; "As coisas não têm medida ou essência própria; são aquilo que nos parecem ser, variando de acordo com as circunstâncias". Outros, finalmente, mostravam-se céticos quanto ao poder do legislador para nomear: "embora hoje, em prol do consenso, nós lhe pusermos um outro nome, o certo é que o cidadão comum continuará chamando de "matrimônio"". Os sofistas, alvo das críticas de Platão, diriam, como vimos, que a língua é uso.

Nem sempre estava claro quando eles estavam falando das palavras como diferentes das coisas, quando das coisas independentemente das palavras, quando da relação entre umas e outras, quando de ambas sendo uma coisa só, mas em todos os discursos podemos encontrar sinais, nem sempre coerentes, da presença daqueles outros discursos inaugurais a respeito da linguagem e da verdade. Vários discursos pronunciados no Parlamento, ouvidos no rádio e nas ruas, em comícios e manifestações a favor ou contra, escritos nos jornais a respeito do uso da palavra 'matrimônio' para se referir às uniões homossexuais refletiam de uma ou de outra maneira o debate dos gregos.

Se a heterossexualidade do matrimônio faz parte de sua "essência", se há uma e só uma coisa na realidade que é "matrimônio" em si, se há uma e só uma maneira de empregar essa palavra com justeza, então as coisas são as mesmas para todos, então há uma realidade essencial que não depende da linguagem e a linguagem tem de servir para falar dessa realidade. Se, pelo contrário, o matrimônio é aquilo que nós decidimos que seja, porque não há verdades essenciais que o definam, mas só usos e práticas sociais cultural e historicamente determinadas, então, é lícito que usemos essa palavra para nos referirmos às uniões entre pessoas do mesmo sexo, porque o significado se define por esses usos e só por eles. Dependendo do caminho que escolhermos, ficaremos mais 
próximos de um discurso ou de outro. Interessou-nos mostrar aqui que, qualquer que seja o caminho tomado, no que tange à linguagem, um senso comum, por assim dizer, "grego", parece ainda impor o seu regime.

\section{Outros caminhos de pesquisa}

À análise dos argumentos apresentados pelas partes e suas relações com diferentes concepções da linguagem precisamos somar uma análise da própria controvérsia, da luta política por uma palavra e suas relações com outras concepções sobre a linguagem.

Nesse sentido, formulamos, em primeiro lugar, duas perguntas:

Por que a oposição ideológica, política ou religiosa ao matrimônio gay apareceu, nas vozes de muitos atores sociais e políticos, disfarçada de "porém" lingüístico? Nas formulações de Foucault (1996) a respeito da vontade de verdade podemos encontrar alguns caminhos de explicação: ao longo da história, a condenação da homossexualidade tem se apoiado em diversos discursos de verdade: a religião, a psiquiatria, a lei etc. Por trás dos argumentos lingüísticos, que se pretendem científicos, contra o matrimônio homossexual, podemos identificar duas operações discursivas: a primeira, que esconde os verdadeiros motivos da oposição, colocando no seu lugar outros que não pareceriam tão "politicamente incorretos" na atualidade — talvez haja aí uma forma de interdição (Foucault, 1996, p. 9); a segunda, que procura nas categorias e conceitos da lingüística uma explicação "científica", "objetiva", revestida de uma série de atributos que reforçariam sua legitimidade, isto é, um "discurso de verdade" (Foucault, 1996, p. 13-21).

Qual é o valor que os movimentos de afirmação da identidade gay/lésbica dão à palavra "matrimônio" na discussão sobre os seus direitos? O lema "os mesmos direitos com os mesmos nomes" evidencia o valor atribuído à igualdade "nominal" junto com a igualdade "material". Essa pretensão aparece atravessada também por vários discursos sobre o poder da linguagem, principalmente por aqueles que enfatizam sua função performativa.

Afirma Foucault (1996, p. 10) que "o discurso não é simplesmente aquilo que traduz as lutas ou os sistemas de dominação, mas aquilo por que, pelo que se luta, o poder do qual nos queremos apoderar”. Um dos argumentos esgrimidos pelos ativistas das organizações LGBT é que se o Estado atribui às uniões homossexuais formalizadas perante a lei uma denominação diferente - respondendo às exigências daqueles que afirmam que isso significa "defender a essência" da instituição matrimonial — haveria nessa decisão uma mensagem simbólica com graves conseqüências. A distinção não poderia ser inocente, mas avaliativa: o Estado estaria estabelecendo duas categorias de famílias às quais, por merecerem diferentes níveis de reconhecimento social, 
correspondem diferentes nomes para seu reconhecimento legal. A linguagem, aqui, não teria a função de representar a realidade, mas a de agir sobre ela. Quem isto escreve sustenta essa idéia e acha que seria mais fácil ela ser compreendida se, em vez de falarmos em homossexuais, falássemos em negros ou judeus, porque a história já se ocupou de nos ensinar muito a respeito das conseqüências do racismo e do antisemitismo. Imaginemos que o matrimônio fosse proibido às pessoas negras e alguém oferecesse, como alternativa, instaurar "uma lei de união de negros". Será que a rosa, sob uma outra designação, teria o mesmo perfume?

A nossa pesquisa deve ainda percorrer outros caminhos para melhor entender a importância da luta política pelas maneiras de nomear as uniões legais entre pessoas do mesmo sexo. A nomeação adquire um valor especial quando o que está em jogo são as identidades de minorias oprimidas, porque a opressão também se exerce no plano do discurso. Sensível a um "clima de opinião" bastante disseminado no contexto da tão falada virada lingüística, Da Silva (2000) afirma que identidade e diferença ("sou negro", "sou homossexual", "sou brasileiro") não são mais do que criaturas da linguagem. Não pertencem ao mundo natural, mas ao mundo social e cultural, e somos nós que as criamos, no contexto de relações culturais e sociais. A relação entre identidade e diferença é crucial. Segundo Woodward (1997), as identidades são formadas relativamente a outras identidades e essa construção aparece, mais comumente, sob a forma de oposições binárias. As oposições, como já explicava Saussure, é essencial para a produção do significado: ser isto significa não ser aquilo. Mas as relações entre isto e aquilo - ou, melhor, entre nós e eles — não são nunca inocentes. Segundo Da Silva, elas encerram marcas da presença do poder. Outros pares binários se associam às diferenças que estabelecemos na construção das identidades: incluir/excluir, valorizar/desvalorizar, normalizar/avaliar como "anormal" etc. Os pronomes "nós" e "eles", mais do que simples categorias gramaticais, são indicadores de posições de sujeito marcadas por relações de poder.

Essas formulações precisam ser aprofundadas. São alguns dos aspectos da nossa pesquisa, ainda em andamento, que deverão ser ampliados.

\section{Referências bibliográficas:}

ACI (Agencia Católica de Informaciones): www.aciprensa.com.

ARISTÓTELES. "De Interpretatione”. In: ANGIONI, L. (trad./org.). Ontologia e predicação em Aristóteles. Campinas: Unicamp, 2000.

BIMBI, Bruno. "Iguales derechos con los mismos nombres". In: Diario La Nación. 
Buenos Aires: 02-03-2007.

BIMBI, Bruno. "El matrimonio gay llega al diccionario". In: Diario Crítica de la Argentina. Buenos Aires: 25-01-2009, pág. 29.

BIMBI, Bruno; LÓPEZ, Gustavo; KRÁVETZ, Florencia. Rachid, María de la Cruz y otros s/medidas precautorias (recurso de amparo presentado por María Rachid y Claudia Castro por el derecho al matrimonio entre personas del mismo sexo). CSJN, Expte. 90/2008, Tomo: 44, Letra: R, Tipo: RHE.

BOSWELL, John. Cristianismo, tolerancia social y homosexualidad. Barcelona: Muchnik Editores, 1992 [1980].

CORTES GENERALES DE ESPAÑA. Congreso de los Diputados. Diario de Sesiones. Sesión plenaria núm. 73, celebrada el jueves, 17 de marzo de 2005. Madrid: Cortes Generales, 2005.

CORTES GENERALES DE ESPAÑA. Congreso de los Diputados. Diario de Sesiones. Sesión plenaria núm. 79, celebrada el jueves, 21 de abril de 2005. Madrid: Cortes Generales, 2005.

CORTES GENERALES DE ESPAÑA. Congreso de los Diputados. Diario de Sesiones. Sesión plenaria núm. 98, celebrada el jueves, 30 de junio de 2005. Madrid: Cortes Generales, 2005.

CORTES GENERALES DE ESPAÑA. Senado. Diario de Sesiones. Sesión del Pleno celebrada el miércoles, 22 de junio de 2005. Madrid: Cortes Generales, 2005.

DA SILVA, Tomaz Tadeu. "A produção social da identidade e da diferença". In: DA SILVA, T. T. (org.), Identidade e diferença. Petrópolis, RJ: Editora Vozes, 2000 [1997].

DIARIO ABC. Madrid: 30-04-2005, Opinión, pág. 5.

DIARIO CLARÍN. Buenos Aires: 05-02-2005:

http://www.clarin.com/diario/2005/02/05/sociedad/s-04201.htm

DIARIO EL MUNDO. Madrid: 30-01-2005:

http://www.elmundo.es/papel/2005/01/30/cronica/1750601.html;

DIARIO EL MUNDO. Madrid: 17-06-2005:

http://www.elmundo.es/papel/2005/06/17/opinion/1818505.html.

DICCIONARIO DE LA REAL ACADEMIA ESPAÑOLA: http://www.rae.es. D ata da consulta: julho de 2009.

FOUCAULT, Michel. A ordem do discurso. Aula inaugural no Collège de France, pronunciada em 2 de dezembro de 1970. São Paulo: Loyola, 1996.

GÓRGIAS. Elogio de Helena. In: CASSIN, Barbara. O efeito sofístico. São Paulo: editora 34, 2005, p.293-301

MARTINS, Helena. "Três caminhos na filosofia da linguagem". In: MUSSALIM, 
Fernanda; BENTES, Anna Christina (orgs.). Introdução à lingüística, Vol. 3. Fundamentos epistemológicos. São Paulo: Cortez, 2009, p. 439-473.

PLATÃO. Diálogos de Platão: Teeteto - Crátilo. Tradução: Carlos Alberto Nunes. Vol. IX. Belém: Ed. U.F.P., 1973 (Coleção Amazônica).

\section{SHLICHTING, Cristina López. "Distorsión del lenguaje". In: http://arvo.net/homosexualidad/distorsion-del-lenguaje/gmx-niv150-con10295.htm}

WOODWARD, Kathryn. "Identidade e diferença: uma introdução teórica e conceitual". In: DA SILVA, T. T. (org.), Identidade e diferença. Petrópolis, RJ: Editora Vozes, 2000 .

\section{NOTAS:}

1 Todos os grifos, em qualquer citação ao longo do trabalho, são nossos.

2 No entanto, segundo pesquisas realizadas por Gallup e CIS, dois de cada três espanhóis eram a favor da lei de matrimônio entre pessoas do mesmo sexo.

3 A Real Academia Espanhola, segundo o seu estatuto, «tem como missão principal velar para que as mudanças que experimente a língua espanhola na sua constante adaptação às necessidades dos seus falantes não quebrem a unidade essencial que ela mantém em todo o âmbito hispânico» (no site da RAE, www.rae.es, "información institucional”).

4 Todas as traduções são nossas.

5 Data da sanção da Constituição espanhola.

${ }^{6}$ Todas as citações de discursos dos deputados e senadores da Espanha foram retiradas dos diários oficiais das "Cortes Generales de España". As referências constam na bibliografia.

7 “(Del lat. matrimonium). 1. m. Unión de hombre y mujer concertada mediante determinados ritos o formalidades legales".

8 Gíria. Ele quer dizer que durante os oito anos em que governaram a Espanha, os direitistas tinham "calado a boca" com relação aos direitos dos casais homossexuais.

9 Segundo os catalães, bascos, valencianos e galegos, mal chamado 'espanhol'.

10 Federação Estatal de Lésbicas, Gays, Transexuais e Bissexuais (da Espanha).

11 Poderíamos dizer que, na verdade, essa contradição existia antes da lei, já que a língua castelhana podia ser usada para se referir aos matrimônios homossexuais de outros países onde ele já era legal ou, mesmo antes disso, para se referir à própria possibilidade de que ele fosse legalizado. E, de fato, isso acontecia há muito tempo.

12 Dizem, mas nunca propõem essas leis quando há maioria nas câmaras.

13 Em particular, os artigos 172 e 188 do Código Civil Argentino, que estabelecem fórmulas de protocolo para a cerimônia de matrimônio civil que, de maneira indireta, impedem que esse seja realizado entre dois homens ou duas mulheres.

$14 \mathrm{O}$ autor deste trabalho é co-autor desse texto.

15 Esse argumento tem sido muito usado nos países hispano-falantes, já que o verbete do dicionário da RAE define o matrimônio dessa maneira, mas o mesmo acontece com os dicionários de outras línguas. Por exemplo, o dicionário Aurélio de português define "matrimônio" como "União legítima de homem com mulher; casamento". Mais adiante, no presente trabalho, veremos que, no entanto, já houve mudanças a respeito disso.

${ }^{16}$ Todos os argumentos citados na enumeração que segue foram retirados desse texto, com exceção do ponto (e), que corresponde a Bimbi (2007).

17 Dicionário Aurélio da língua portuguesa, versão digital 5.0.

18 Se aceitarmos que houve algo na antiga Roma que pode ser considerado um antecedente do matrimônio de hoje e se esse "algo" incluía casais do mesmo sexo, devemos admitir que eles também fazem parte da história da instituição... e do termo. Para Boswell (1980, p. 49), “insistir em que, para constituírem 'matrimônios', as uniões homossexuais do passado deviam ser análogas ao matrimônio heterossexual moderno é desafiar a história. Nenhum matrimônio das sociedades antigas guarda estreita semelhança com seus equivalentes modernos. A maioria era muito mais informal; alguns, mais rígidos. A maioria das culturas considerava o matrimônio como um acordo particular que se negocia entre duas famílias. (...) [Para aquele período] é impossível especificar critérios de 'legalidade' de um matrimônio: duas pessoas que viviam juntas em forma permanente e cuja união era reconhecida pela comunidade 
estavam "casadas"”. O autor também afirma, entre outros exemplos históricos, que o imperador romano Nero casou duas vezes com homens, em cerimônia pública e segundo os rituais adequados para o matrimônio legal naquela época.

19 A discussão sobre o argumento naturalista é muito mais ampla e tem merecido não só textos em jornais e revistas, como também livros e teses de doutorado. A complexidade dela ultrapassa completamente os objetivos deste trabalho, mas consideramos importante salientar que ela tem uma importância particular, já que nela se juntam duas questões cruciais para este debate: a) a tese da origem natural dos nomes, tal como acima apresentada a partir do Crátilo, e b) a tese de que a homossexualidade contraria uma ordem natural, argumento que tem sido usado não apenas neste debate, como em todos os debates que têm a ver com a homossexualidade.

Como explica Boswell (1980), o uso da palavra "natureza" e outras de sua família semântica para desprezar a homossexualidade - e, neste caso, o matrimônio homossexual - provém de uma interpretação de um versículo da Bíblia que faz referência às relações "contra-natura". Independentemente de aceitarmos ou não a tese de que a Bíblia seja uma fonte de autoridade à respeito da natureza, Boswell expõe argumentos e evidências que sustentam a tese de que aquela interpretação inaugural do texto bíblico, que abriu um longo percurso de construções discursivas a respeito da homossexualidade, está errada. Para isso, ele compara as traduções da Bíblia que se usam na atualidade com os exemplares mais antigos de versões desses textos que ainda se conservam, em hebraico, grego e outras línguas, e oferece evidências de que as palavras que foram traduzidas como "contra-natura" e, depois, interpretadas como se referindo a homossexualidade (termo que, na época em que os textos que compõem a Bíblia foram escritos, não existia) aludiam a conceitos diferentes aos que atualmente são compreendidos em nossa cultura. Ele demonstra inclusive que os mesmos termos, presentes em diferentes trechos da Bíblia, foram traduzidos com palavras diferentes, dependendo do sentido que as traduções pretenderam atribuir-lhes - ele diz que propositalmente - em cada trecho. Boswell ainda apresenta diferentes noções de 'natureza' que existiram em diferentes períodos históricos da cultura ocidental e cujos vestígios ainda existem nos múltiplos sentidos que atualmente atribuímos a essa palavra em diversos contextos de uso.

Os discursos que falam da homossexualidade em termos de natural / não-natural imprimem a essa dicotomia uma carga avaliativa que poderia se associar à oposição bom / mau, o que não faria parte do conceito de "natureza" dos antigos - ou, mas precisamente, do conceito que eles associassem às palavras das suas línguas que hoje nós traduzimos por natureza em português. Nesse sentido, Boswell apresenta evidências que permitem supor que a palavra grega que é traduzida por "contra-natura" nas versões ocidentais contemporâneas do Antigo Testamento significava algo parecido a "não-habitual" ou "não-corrente", conceitos estes que não levavam consigo nenhum traço semântico que indicasse que isso fosse bom ou mau, melhor ou pior, correto ou incorreto.

Para uma análise mais clara e detalhada, aconselhamos a leitura das obras de Boswell. No entanto, o dito até aqui permite explicar por que a associação do matrimônio heterossexual com a "natureza" e a idéia de que o matrimônio homossexual seria "antinatural" está inscrita numa longa tradição discursiva que, a partir de uma determinada interpretação semântica de termos usados em textos antiquíssimos, impôs uma justificativa religiosa para avaliar negativamente a homossexualidade que, ao longo dos últimos séculos, ingressou no universo dos nossos pressupostos culturais. Todo esse caminho, porém, está escondido atrás de um discurso que se apresenta mais simples, mais óbvio e mais "objetivo". 